\title{
Outcomes of various types of therapy in patients with treatment-resistant acrodermatitis continua of Hallopeau
}

This article was published in the following Dove Press journal: Biologics: Targets and Therapy

\section{LM Smirnova \\ E Yu Vertieva \\ O Yu Olisova \\ EM Anpilogova}

Department of Dermatology and Venereology, I.M. Sechenov First Moscow State Medical University, Moscow I |999I, Russian Federation
Correspondence: EM Anpilogova Department of Dermatology and Venereology, I.M. Sechenov First Moscow State Medical University, 4 Bolshaya Pirogovskaya Street, Building I, Moscow I 19435, Russian Federation

$\mathrm{Tel}+79162117080$

Email truelass@hotmail.com
Background: Chronic acrodermatitis continua of Hallopeau (ACH) is a rare form of pustular psoriasis predominantly affecting the distal phalanges of the fingers and toes. The disease manifests by pustular rash with marked infiltration, fissures, and often results into severe dystrophy of nail plates. ACH is refractory to most of psoriasis standard of care (SOC) therapies.

Objective: The objective of this study is to assess the prospects of secukinumab therapy of $\mathrm{ACH}$ based on current clinical observation.

Methods: We observed a female patient with ACH. Number of SOC treatments were applied in that case including local PUVA therapy, systemic retinoids, methotrexate, and biologic agents.

Result: Secukinumab, a IL-17 inhibitor, demonstrated pronounced clinical effect in the case of ACH refractory to other SOC therapies.

Conclusion: IL-17 inhibition provided by secukinumab was linked to clinically meaningful improvement in the heavily pretreated ACH. Further exploration and clinical studies may be important to provide more data on secukinumab effects in $\mathrm{ACH}$.

Keywords: acrodermatitis continua of Hallopeau, secukinumab, apremilast, anti IL-17A therapy, phosphodiesterase-4

\section{Introduction}

Acrodermatitis continua of Hallopeau $(\mathrm{ACH})$ was first described by Henri Hallopeau in 1890. Currently, this disease is classified as a rare form of palmoplantar pustular psoriasis (PPP). ${ }^{1} \mathrm{ACH}$ is a chronic inflammatory dermatosis which is characterized by sterile pustules on the distal phalanges of the fingers and toes. Continuous inflammation results in severe finger and toe damage, onychodystrophy, and sometimes anonychia and osteolysis. ${ }^{2}$ Cases of transformation of $\mathrm{ACH}$ into generalized pustular psoriasis (GPP) have been observed. Usually ACH manifests at 1-2 fingers or toes. Most commonly it is observed in women after palmar or foot injuries or infections. ${ }^{3}$

Histological findings in ACH include formation of neutrophilic pustules, degenerative changes in epidermal cells, and moderate lymphohistiocytic infiltration. ${ }^{2}$

Typically, ACH demonstrates low or no stable response to SOC treatments. Multiple therapies include methotrexate, systemic retinoids, cyclosporin A, biologics (adalimumab, infliximab), and others; however, none of the current treatments results into the longer term disease control. ${ }^{4-6}$ Here our experience of ACH treatment is presented. 


\section{Case}

A 53-year-old female patient was observed for $\mathrm{ACH}$ at the Clinic of Dermal and Venereal Diseases, Sechenov University (Moscow). ACH manifested in 2014 after stress. Physical examination revealed pustular rash primarily on the distal phalanges of the fingers and toes: marked infiltration was associated with pustules, areas of hyperkeratosis, and fissures were detected. Severe dystrophy affected the nail plates; the nails were thickened, yellow, and brittle; onycholysis was observed. No pathogenic fungi detected. Diagnostic biopsy of a nail fold followed by histological examination revealed numerous neutrophils in the keratinized layer of the epidermis, epidermal hyperplasia, and hyperkeratosis typical of ACH. A course of local PUVA therapy (with Ammifurin as a photosensitizer) was started in 2015; no improvement was observed after 20 sessions with a cumulative dose of $60 \mathrm{~J}$ (Figure 1). In subsequent years, the patient was treated with methotrexate, systemic retinoids, and infliximab. Please see Table 1 for details.

Following previous treatment failures, apremilast therapy was initiated in 2017. The dose was escalated from $10 \mathrm{mg} /$ day to $30 \mathrm{mg}$ twice daily (Table 2). Adverse events observed during the first 3 weeks after startup of the therapy included severe diarrhea and nausea; these events were subsequently resolved. The pustules had regressed and the infiltration improved by the end of the second month of therapy; however, no re-growth of healthy nail plates occurred. Thus, methotrexate $25 \mathrm{mg} /$ week was added. However, no further improvement was observed on apremilast/MTX combination (Figure 2).

So, given the questionable result of the standard therapy, the course of secukinumab was started, as per existing
Table I Use of various types of therapy in a 53-year-old female patient with acrodermatitis continua of Hallopeau

\begin{tabular}{|c|c|c|}
\hline Date & Drug & Outcome \\
\hline 2015 & $\begin{array}{l}\text { Local PUVA therapy } 4 \text { times } \\
\text { per week, } 20 \text { sessions in } \\
\text { total. Cumulative dose: } 60 \mathrm{~J}\end{array}$ & No effect \\
\hline 2015 & $\begin{array}{l}\text { Systemic retinoids } \\
\text { Isotretinoin } 0.7 \mathrm{mg} / \mathrm{kg} \text { - } \\
40 \mathrm{mg} / \text { day for } 4 \text { months }\end{array}$ & $\begin{array}{l}\text { Discontinued after } 4 \\
\text { months, } \\
\text { low efficacy }\end{array}$ \\
\hline 2016 & $\begin{array}{l}\text { Methotrexate } 25 \mathrm{mg} / \text { week } \\
(3 \text { weeks), followed by } \\
15 \mathrm{mg} / \text { week ( } 3 \text { weeks) }\end{array}$ & $\begin{array}{l}\text { Discontinued due to low } \\
\text { efficacy }\end{array}$ \\
\hline 2017 & $\begin{array}{l}\text { Infliximab } 5 \mathrm{mg} / \mathrm{kg} \text { on weeks } \\
0,2 \text { and } 6 \text { weeks }\end{array}$ & $\begin{array}{l}\text { Mild effect, } \\
\text { no effect on nail plate } \\
\text { growth }\end{array}$ \\
\hline 2017 & $\begin{array}{l}\text { Apremilast, with dose titra- } \\
\text { tion to } 30 \mathrm{mg} \text { twice daily }\end{array}$ & $\begin{array}{l}\text { Marked effect on skin man- } \\
\text { ifestations, no effect on nail } \\
\text { plate growth }\end{array}$ \\
\hline 2017 & Apremilast + Methotrexate & $\begin{array}{l}\text { Marked positive effect on } \\
\text { skin manifestations, } \\
\text { No effect on nail plate } \\
\text { growth }\end{array}$ \\
\hline 2018 & $\begin{array}{l}\text { Secukinumab } 300 \mathrm{mg} \text { per } \\
\text { week on weeks } 0, \mathrm{I}, 2,3 \text {, } \\
\text { then } 300 \mathrm{mg} \text { monthly }\end{array}$ & $\begin{array}{l}\text { Marked positive effect; } \\
\text { re-growth of healthy nail } \\
\text { plates }\end{array}$ \\
\hline
\end{tabular}

data, secukinumab showed some clinical benefits in generalized pustular psoriasis (referral). So, it was decided to include it in the treatment plan of the current case.

Secukinumab was dosed as per approved regimen: $300 \mathrm{mg}$ per week by subcutaneous injections (weeks 0 , 1, 2, 3), followed by $300 \mathrm{mg}$ once monthly. Concomitant active infections, including tuberculosis, were ruled out prior to the start of treatment. Up to date, six injections
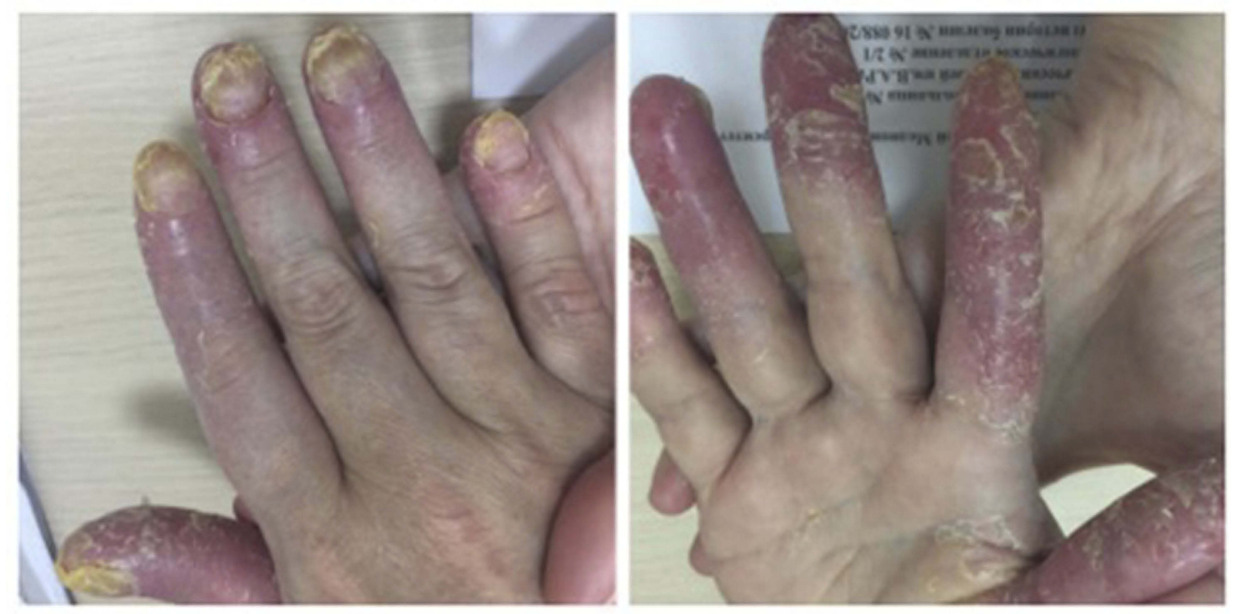

Figure I Patient with acrodermatitis continua of Hallopeau: condition on admission. 
Table 2 Apremilast dosing regimen

\begin{tabular}{|l|l|l|l|l|l|l|l|l|l|l|}
\hline Day I & \multicolumn{2}{|l|}{ Day 2 } & \multicolumn{2}{l|}{ Day 3 } & \multicolumn{2}{l|}{ Day 4 } & \multicolumn{2}{l|}{ Day 5 } & \multicolumn{2}{l|}{$\begin{array}{l}\text { Day } 6 \text { and } \\
\text { afterwards }\end{array}$} \\
\hline Morning & Morning & Evening & Morning & Evening & Morning & Evening & Morning & Evening & Morning & Evening \\
\hline $10 \mathrm{mg}$ & $10 \mathrm{mg}$ & $10 \mathrm{mg}$ & $10 \mathrm{mg}$ & $20 \mathrm{mg}$ & $20 \mathrm{mg}$ & $20 \mathrm{mg}$ & $20 \mathrm{mg}$ & $30 \mathrm{mg}$ & $30 \mathrm{mg}$ & $30 \mathrm{mg}$ \\
\hline
\end{tabular}
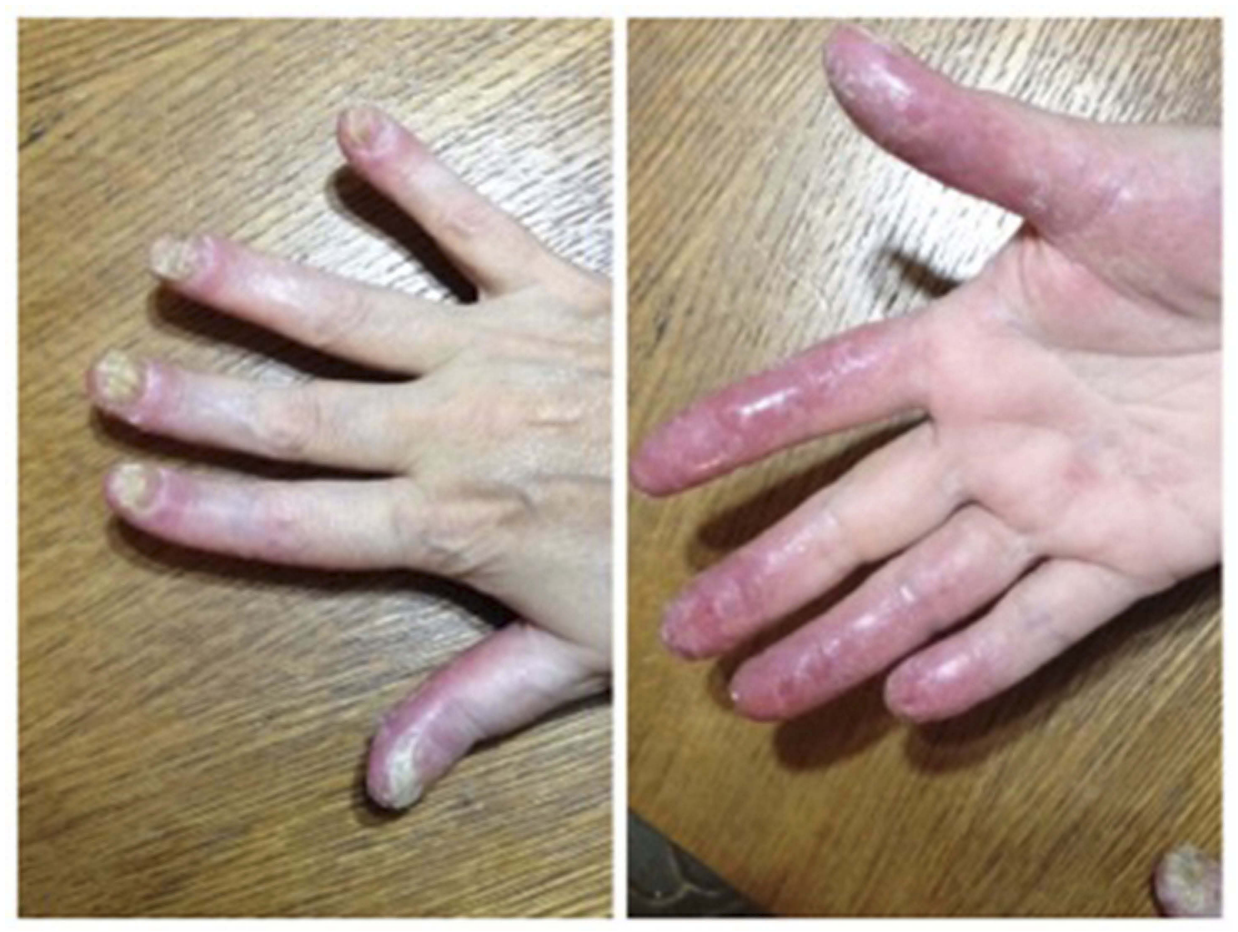

Figure 2 Patient's condition after the apremilast course.

were applied, and the treatment is ongoing. A marked early improvement (regression of pustular rash elements and decrease of inflammation) was observed after the third administration. After the fourth injection, re-growth of healthy nail plates was detected (see Figure 3).

\section{Discussion}

$\mathrm{ACH}$ is a difficult to treat disease refractory to the majority of SOC psoriasis therapies. The nail plates involvement makes it especially difficult to achieve a clinical improvement. In most cases, standard treatment with local PUVA therapy, systemic retinoids, and methotrexate, results in partial regression of skin symptoms but has no effect on the manifestations and natural course of onychodystrophy.

Apremilast therapy may be applied, as there is a considerable body of evidence of its efficacy along with a reasonable safety profile. As intracellular phosphodiesterase-4 (PDE-4) inhibitor, apremilast modulates proinflammatory pathways. PDE-4 inhibition results in increased cAMP production and drives down expression of pro-inflammatory cytokines including TNF-alpha, IL23, and IL-17. In our case, apremilast resulted in partial response, as pustular rash regressed, infiltration and hyperkeratosis decreased. However, severe nail plate dystrophy persisted.

According to the latest data, IL-17 suppression provided by secukinumab is effective in the treatment of psoriasis and psoriatic arthritis ${ }^{1,6-8}$ and demonstrated notable anti-inflammatory effects. Secukinumab is a fully human IgG1 which targets and inhibits IL-17A. IL-17 was shown to have an essential role in the proinflammatory processes in psoriasis: it directly affects keratinocytes causing their hyperplasia, acanthosis, and 

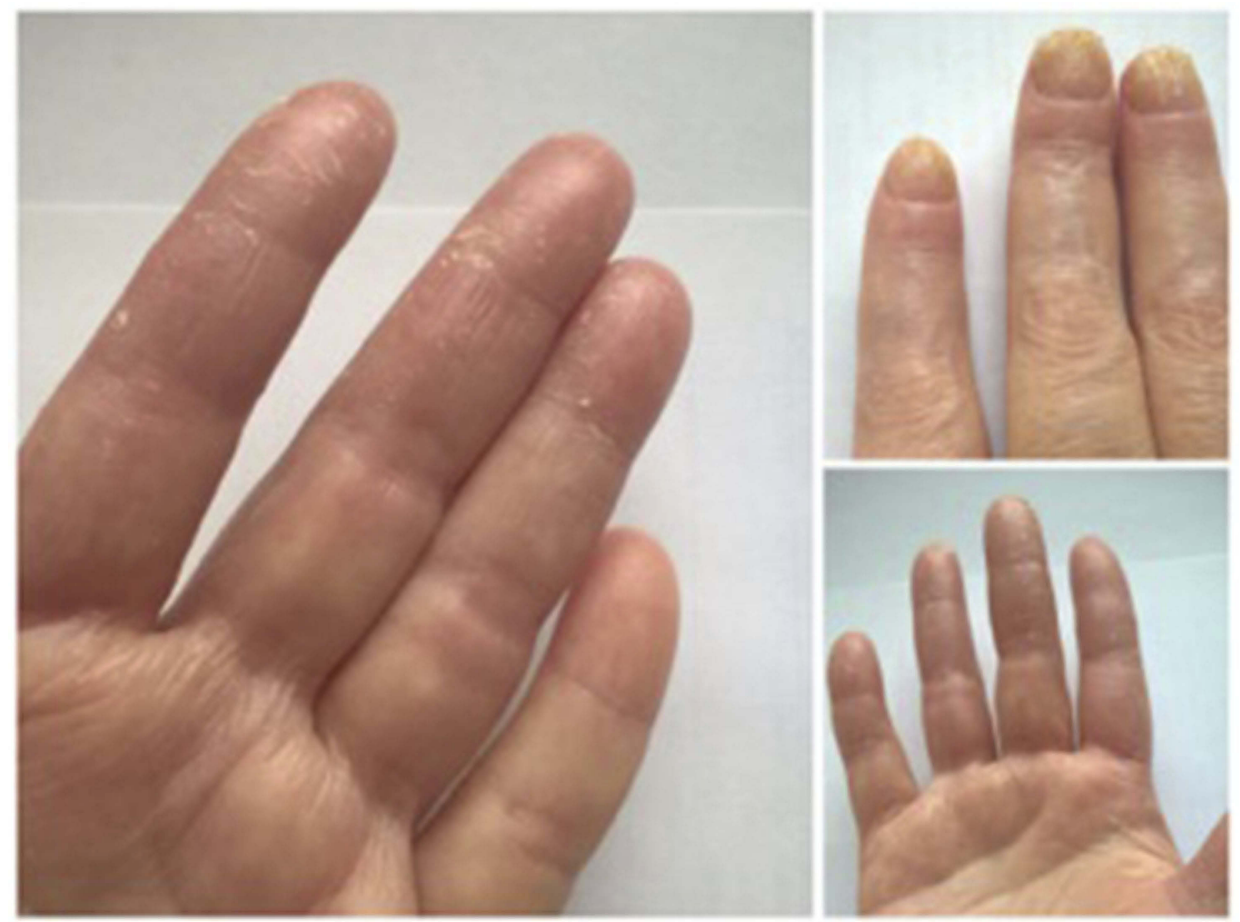

Figure 3 Patient's condition after six secukinumab injections.

hyperkeratosis. It leads to accumulation of neutrophils and T-lymphocytes in the epidermis and further escalation of chronic inflammation. ${ }^{6,7}$

\section{Conclusion}

IL-17 mRNA levels have been shown to be significantly elevated in generalized pustular psoriasis (GPP). ${ }^{9}$ In view of the common histological changes and pathogenesis of GPP and $\mathrm{ACH}$, secukinumab has a potential to become the treatment of choice and potential standard of care in $\mathrm{ACH}$. The further investigation of IL-17 role in ACH will be needed to determine the longer term clinical effects and future place of secukinumab and other IL-17 inhibitors in the treatment pattern of refractory dermatosis.

\section{Ethics statement}

Written informed consent has been provided by the patient to have the case details and all images published. No institution approval was required to publish the case details.

\section{Disclosure}

The authors report no conflicts of interest in this work.

\section{References}

1. Muggli D, Maul J-T, Anzengruber F. Secukinumab for acrodermatitis continua of Hallopeau. JAMA Dermatol. 2017;153(4):336-337. doi:10.1001/jamadermatol.2016.5059

2. Sehgal VN, Verma P, Sharma S, et al. Review acrodermatitis continua of Hallopeau: evolution of treatment options. Int $J$ Dermatol. 2011;50:1195-1211. doi:10.1111/j.1365-4632.2011.05008.x

3. Mrowietz U. Pustular eruptions of palms and soles. In: Wolff K, Goldsmith LA, Katz SI, editors. Fitzpatrick's Dermatology in General Medicine, 7th. New York, NY: McGraw-Hill; 2008:215-218.

4. Dini V, Barbanera S, Romanelli M. Efficacy of adalimumab for the treatment of refractory paediatric acrodermatitis continua of Hallopeau. Acta Derm Venereol. 2013;93:588-589. doi:10.2340/00015555-1540

5. Lefkir S, Slimani S, Brahimi N, Ladjouze-Rezig A. Successful treatment of acrodermatitis continua of Hallopeau associated with psoriatic arthritis with adalimumab. Eur $J$ Rheumatol. 2015;2:78-79. doi:10.5152/eurjrheum.2015.0072

6. Frew JW, Murrell DF. Highly resistant acrodermatitis continua of Hallopeau and pustular psoriasis. Skin Appendage Disord. 2017;3:179-181. doi:10.1159/000464140

7. Balestri R, Rech G, Tasin L, Rizzoli L, Girardelli CR. Acrodermatitis continua of Hallopeau successfully treated with secukinumab. J Dermatolog Treat. 2018;29:3-5. doi:10.1080/09546634.2018.1527993

8. Baron JA. Acrodermatitis of Hallopeau and erosive oral mucositis successfully treated with secukinumab. JAAD Case Rep. 2017;3:215-218. doi:10.1016/j.jdcr.2017.02.016

9. Lee E, Zarei M, LaSenna C, Villada G, Romanelli P. Psoriasis targeted therapy: characterization of interleukin 17A expression in subtypes of psoriasis. J Drugs Dermatol. 2015;14(10):1133-1136. 


\section{Publish your work in this journal}

Biologics: Targets and Therapy is an international, peer-reviewed journal focusing on the patho-physiological rationale for and clinical application of Biologic agents in the management of autoimmune diseases, cancers or other pathologies where a molecular target can be identified. This journal is indexed on PubMed Central, CAS, EMBase,
Scopus and the Elsevier Bibliographic databases. The manuscript management system is completely online and includes a very quick and fair peer-review system, which is all easy to use. Visit http://www.dovepress.com/testimonials.php to read real quotes from published authors.

Submit your manuscript here: https://www.dovepress.com/biologics-targets-and-therapy-journal 